\title{
Assessments of seasonal groundwater recharge and discharge using environmental stable isotopes at Lower Muda River Basin, Malaysia
}

\author{
Mohd Khairul Nizar Shamsuddin ${ }^{1,2}$ (D) Wan Nor Azmin Sulaiman ${ }^{2} \cdot$ Mohammad Firuz Ramli $^{2} \cdot$ \\ Faradiella Mohd Kusin ${ }^{2} \cdot K$ amarudin Samuding ${ }^{3}$
}

Received: 1 November 2017 / Accepted: 5 July 2018 / Published online: 13 July 2018

(c) The Author(s) 2018

\begin{abstract}
An accurate estimation of groundwater recharge is required to properly manage aquifers, especially for riverbank filtration method (RBF) purposes. The isotopes correlations and differences in different water bodies were studied to assess the sources of groundwater recharge and preliminary tools in understanding of the surface water and groundwater interactions in the Lower Muda River Basin. The environmental isotope and hydrochemical sampling results had emphasised that the area near Lower Muda River Basin had a connection with the river and was actively recharging the near-river shallow alluvial aquifer, via RBF method. Furthermore, the shallow groundwater that was close to Muda River from groundwater signatures had indicated the recharge of the shallow aquifer system by Muda River based on the plots along LMWL on a $\delta^{2} \mathrm{H}$ versus $\delta^{18} \mathrm{O}$. The comparisons between like $\delta^{2} \mathrm{H}$ and $\delta^{18} \mathrm{O}$ isotopes in the rainwater revealed the variations in the rainfall amount and the ${ }^{18} \mathrm{O}$-depleted water of those isotopes for wet season precipitation as compared to dry seasons. Furthermore, the groundwater $\delta^{2} \mathrm{H}$ and $\delta^{18} \mathrm{O}$ isotopes exhibited a slight deviation from the $\delta^{2} \mathrm{H}$ and $\delta^{18} \mathrm{O}$ isotopic meteoric water line in Lower Muda River. Therefore, in this basin, the groundwater could be a combination of river water and precipitation, which had led to the recharge of river water being more than the recharge of rainfall infiltration.
\end{abstract}

Keywords Water isotopes $\cdot$ Unsaturated zone $\cdot$ Groundwater recharge $\cdot$ Muda River Basin $\cdot$ Malaysia

\section{Introduction}

Assessment of groundwater recharge is important in the management of groundwater resources (Hooji et al. 2011; Scanlon et al. 2006) because recharge is not a continuous process and is instead a sporadic event, observing and analysing it is extremely difficult. That has been a difficult challenge for hydrogeologists, made more difficult by the dual influence that human activities and climate change have had during the last three decades. Recent years have seen a growing trend in water consumption which corresponded to

Mohd Khairul Nizar Shamsuddin

nizar@nahrim.gov.my

$1 \quad$ Hydrogeology Research Centre, National Hydraulic Research Institute of Malaysia, Lot 5377, Jalan Putra Permai, 43300 Seri Kembangan, Selangor, Malaysia

2 Faculty of Environmental Studies, Universiti Putra Malaysia, 43400 Serdang, Selangor, Malaysia

3 Environmental Division, Malaysian Nuclear Agency, 43000 Bangi, Kajang, Selangor, Malaysia the continuous economic development (Dalin et al. 2017). Overexploitation of groundwater resources has led to water depletion, declining of groundwater levels, and deterioration of water quality (Custodio 2002; Blasch and Bryson 2007; Kumar 2007; Brunner et al. 2014; Unsal et al. 2014; TamezMeléndez et al. 2016). All those conditions are the threats to reliable water supplies and economic development. This is a serious situation, especially in semi-arid and arid areas because they often rely on groundwater as their main source for their irrigation, industrial, and domestic supply (Taylor et al. 2013). The role that it plays in the development of regional economy is so important that it becomes an indispensable source of water in those areas. Therefore, obtaining information about recharge mechanism is vital in being able to rationally use the groundwater resource.

Estimating recharge with the use of traditional hydrogeological methods (e.g. water balance methods, lysimeters, and Darcy's method) is influenced by methodological difficulties (Grindley 1969; Hough and Jones 1998; Chapman and Malone 2002; Yeh et al. 2004). On the other hand, a better understanding of aquifer recharge can be gained by 
monitoring isotope changes. Isotope methods are often considered as unique tools that offer insights into processes of groundwater recharge and the systems of groundwater flow. Furthermore, they have been in extensive use in various regions (Bhattacharya et al. 1985; Krishnamurthy and Bhattacharya 1991; Zhang et al. 2005; Blasch and Bryson 2007; Li et al. 2008; Yuan et al. 2011), especially when conditions are arid and semi-arid for several years (IAEA 2011). Specifically, $\delta^{2} \mathrm{H}$ and $\delta^{18} \mathrm{O}$ are considered ideal conservative tracers that offer insights into the groundwater system's recharge and flow since they make up the actual water molecule and their compositions remain the same unless the flow path has phase changes or fractionation (Clark and Fritz 1997). Therefore, groundwater would retain its isotopic fingerprint, which a reflection of its origin and history prior to infiltration. The groundwater isotopic content is dependent on the recharge isotopic content. Groundwater that goes through direct infiltration from precipitation possesses precipitation's isotopic signature. On the other hand, the groundwater that is recharged using other sources like rivers and lakes will reveal the contributing river or lake mean isotopic content. Furthermore, their signature is expected to vary from that of local precipitation (IAEA 2011). That makes it possible to trace the recharge water source and flow path by examining the differences in the isotopic signature of various different waters (Craig 1961; Onodera et al. 1995; Lee and Lee 1999; Coplen et al. 2000; Vandenschrick et al. 2002; Ma et al. 2007; Mukherjee et al. 2007; Kyle and Jeannie 2007; Palmer et al. 2007; Yeh et al. 2009, 2011; Mandal et al. 2011).

In the Lower River Muda Basin, groundwater and surface waters are the major water supply source for paddy fields and they are also a part of an area that is more popularly known as the rice bowl of Malaysia. This area measures $4150 \mathrm{~km}^{2}$. The Lower Muda Basin's water sources are essential in various important key economic sectors such as industry, services, agriculture, tourism, and paddy planting for Seberang Perai, central and south Kedah, and also for Pulau Pinang. Malaysia's northern states form the key portion of the Northern Corridor Development Region (NCDR). Next to the central region, they also have the second highest growth domestic product (GDP). Furthermore, this area possesses Malaysia's largest granary IADA (Integrated Agriculture Development Area) scheme, which measures about 100,000 ha and is responsible for approximately $40 \%$ of the country's total paddy production. The Lower River Muda Basin is a vital river because it serves as the main source of water for the potable water and irrigation of southern Perlis, Kedah, and Pulau Pinang. Thus, it is right for the river to be given due recognition and priority in the appropriate management of water resources to supply enough water resource and support the development of the regional corridor. The rise in water demand, which is mainly for potable water supply and agriculture, has led to water stress in the area which is made more apparent, especially during dry seasons. Water allocation conflicts have also become more pronounced among the different users and water use sectors from different states that depend on the same source of water. The issue gains more complexity since the dams and river infrastructures are being managed and developed by several various agencies from the federal to the state levels. In order to address these water issues that are expected to become more acute, the Riverbank Filtration (RBF) programme has started the development of tools to aid stakeholders in making informed decisions (Shamsuddin et al. 2014). The tool includes the conjunctive use of water resources between the ground and surface waters. The tool was also developed specifically for the basin. Thus, gaining an understanding of the current recharge to aquifer is a pressing need for water managers and hydrogeologists. This issue also involves some previous studies. Majority of these works utilised traditional methods of numerical modelling or hydrogeological investigations (e.g. Shao et al. 2006; Yang et al. 2009). Shao's (1989) study presented the first discussion about the mechanism and origin of groundwater recharge with the use of environmental tracers. However, the sources and processes of the current recharge in the Lower River Muda basin have not had any good demonstrations yet. Previous works suggest strong connections between groundwater aquifers and rivers (Sear et al. 1999; Jasechko et al. 2016). Thus, to further plan sustainable groundwater management, it is important to identify the groundwater recharge's sources and their relative contributions to the present hydrogeological situation. The aims are to determine (1) the possible groundwater sources, (2) the seasonal differences in groundwater recharge, and (3) processes of recharge to aquifer with the use of stable isotopes $\left(\delta^{2} \mathrm{H}\right.$ and $\delta^{18} \mathrm{O}$ ) and the hydrochemistry of Lower Muda River area's surface and groundwaters. The results offer vital information about hydrological processes like interaction among the river water, precipitation, and groundwater.

\section{Study area}

The study area is the Muda River Basin that is situated in the northwestern portion of Peninsular Malaysia. The basin's upper and middle reaches are part of the State of Kedah, and the downstream of the river forms a boundary between the States Penang and Kedah. The Muda River has undergone development as one of the most vital water resources for water supply and agriculture in the states of Kedah and Penang. Kedah and Penang both have the rights to utilise the water from the Muda River. The area of the study is found between $100^{\circ} 29^{\prime} 0^{\prime \prime} \mathrm{E}$ and $100^{\circ} 33^{\prime} 30^{\prime \prime} \mathrm{E}$ east longitudes and $5^{\circ} 31^{\prime} 30^{\prime \prime}$ and $5^{\circ} 35^{\prime} 30^{\prime \prime}$ north latitude and covers an area that 
measures 150 sq.km. The sub-basin has a tropical climate and receives rain due to the influence of two typical monsoons, namely the southwest monsoon (May to August) and the northeast monsoon (November to February). During the period of transition between the two monsoons, westerly winds are dominant from September to November and they lead to the heaviest amount of annual rainfall precipitation within the study area. Therefore, there is a tendency for the study area to have two rainy seasons in 1 year: one that happens from April to May and another one that takes place from September to November. In the two states, the average air temperature is approximately $27^{\circ} \mathrm{C}$. Agriculture is the most important economic activity, with paddy being the chief crops being raised. Kedah and a portion of Penang state serve are considered a vital important Malaysian agricultural area, popularly known as the rice bowl. It possesses the largest double cultivation paddy field $(97,000$ ha) that serves as the Malaysians' main food source.

\section{Geology and hydrogeology}

The study area's quaternary stratigraphy is divided into the Gula Formation and the Beruas Formation. The Beruas Formation is the uppermost layer and is made up of Holocene terrestrial sediments that are brownish in colour. The Gula Formation is underlying the Beruas Formation. It is made up of silt, clay, and sand with shells. The Gula Formation serves as an impermeable layer, which confines the other formations that are situated beneath it. The classifications of these units are based on age, lithology, and environment of deposition as defined by Bosch (1986), Suntharalingam and Teoh (1985), and Kamaludin (1990). Gula Formation unit is made up of mainly grey to greenish grey that are deposited within marine to subordinate sand and estuarine clay. The formation's thickness differs from 1 to $25 \mathrm{~m}$. Beruas Formation is considered the younger formation within the study area and is deposited in the fluviatile-estuarine-lacustrine that consists of clay, sandy gravel, sandy clay, peat, and silt. Lithologically, the Gula Formation is made up of silt, sand, clay, some gravel, and peat that often have shell fragments. It is thought that this Holocene unit is deposited within a shallow marine environment and an estuarine. The Holocene Beruas Formation is considered a fluvial deposit that is made up of sand, clay, gravel, silt, and the occasional peat (Kamaludin 1989). This formation in the study area differs in thickness from a metre to less than $15 \mathrm{~m}$. The potential of the groundwater aquifers could be seen around Kepala Batas and have a significant amount of gravel and sand layers with a thickness that ranges between 12 and $27 \mathrm{~m}$ (Kamaludin 1990). A large part of the Seberang Perai area is underlain by the sedimentary rocks and pre-Quaternary (Courtier 1974). Furthermore, the Seberang Perai coastal area is also underlain by Gula Formation, Simpang Formation, and Beruas
Formation, which are quaternary in age. Additionally, the Pleistocene Simpang Formation, which consists of gravel, clay, sand, and local peat and silt, has been considered a fluvial, terrestrial deposit. Generally, the top layer for all boreholes logging possessed a semi-permeable layer such as clayey sand that measures 1-9 $\mathrm{m}$ in thickness from ground level (Fig. 1). Permeable material with thickness of 9-24 m was also found underneath the semi-permeable material. All the boreholes demonstrated the same compositions for the permeable materials, which are made up of sandy gravel. The hard layer marine clay is found at a depth of 36-40 m from ground level. The values of permeability vary from 13.65 to $24.36 \mathrm{~m} /$ day. The values of transmissivity range from 64 to $125 \mathrm{~m}^{2} / \mathrm{h}$. The aquifer specific capacity ranged from 43.92 to $128 \mathrm{~m}^{3} / \mathrm{h}$. The values of the piezometer head during pre-monsoon varied between 2.44 and $4.47 \mathrm{~m}$ below ground level, while it varied from 1.6 to $3.64 \mathrm{~m}$ below ground level after the monsoon seasons.

\section{Materials and methods}

$\delta^{2} \mathrm{H}-\delta^{18} \mathrm{O}$ serve as sources of groundwater recharge. Stable isotopes $\left(\delta^{18} \mathrm{O}\right.$ and $\left.\delta^{2} \mathrm{H}\right)$ in water that contain their origin's fingerprint characteristics are influenced by meteorological processes, which means that they can therefore be used by means to trace their origin (Clark and Fritz 1997). River water, groundwater, and precipitation samples were collected for the analyses of $\delta^{2} \mathrm{H}$ and $\delta^{18} \mathrm{O}$ isotopic from the periods of 2014-2016. Sampling was performed during both dry and wet periods. The study also conducted sampling for $\delta^{2} \mathrm{H}$ and $\delta^{18} \mathrm{O}$ isotopic compositions for the 25 locations using samples of surface water (rivers), groundwater (pumping wells and monitoring wells), and precipitation (rainfall). Table 1 and Fig. 1 illustrate the sampling locations. Approximately 120 samples were taken from the test wells and monitoring wells, and seven samples were obtained from the rivers (Muda River). The samples that were taken from the surface water were labelled SW (Muda River). The samples of the groundwater were obtained from the $\mathrm{BH} 1, \mathrm{BH} 2, \mathrm{BH} 3, \mathrm{BH} 4, \mathrm{BH} 5, \mathrm{BH} 6, \mathrm{BH} 7, \mathrm{BH} 8, \mathrm{BH} 10$, BH12, BH13, BH15, BH16, BH17, ВH18, ВH19, ВH20, BH21, BH22, TW1, TW2, TW3, and TW4 wells, which were considered to be from an aquifer. Furthermore, the rainwater samples were labelled as (RW). Measurement of the stable isotope contents for the samples of groundwater, surface water, and rainwater was taken at the Isotope Hydrology Laboratory of the Malaysian Nuclear Agency. All the water samples collected for the stable isotopes were measured for $\delta^{2} \mathrm{H}$ and $\delta^{18} \mathrm{O}$ with the use of the SerCon GEO $20-20^{\circledR}$ Continuous Flow Isotope Ratio Mass Spectrometer (CF-IRMS). For the sampling of $\delta^{2} \mathrm{H}$ and $\delta^{18} \mathrm{O}$, the water samples were made to fully fill $100-\mathrm{mL}$ HDPE bottles to

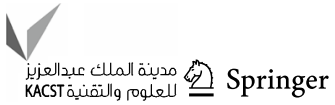



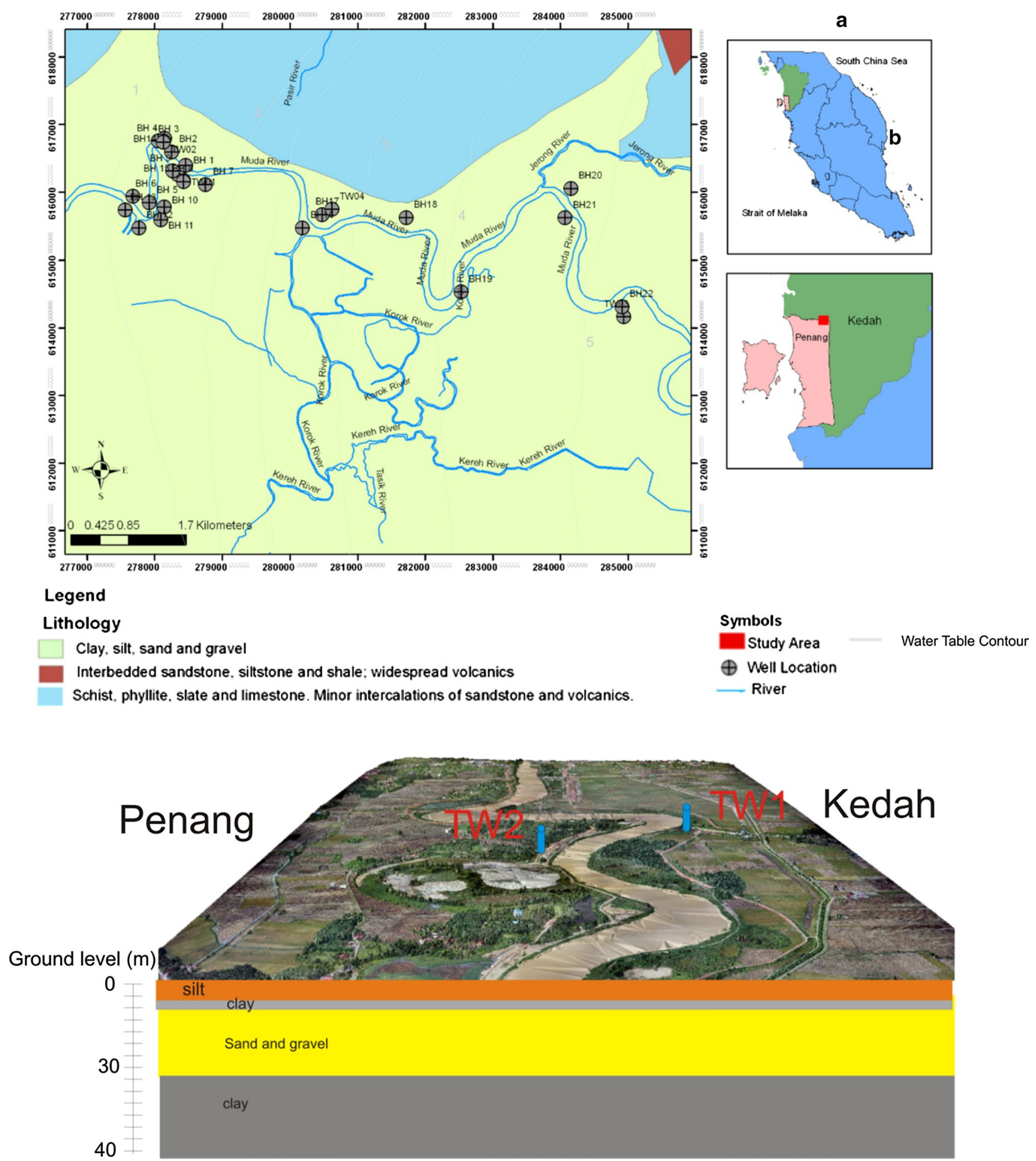

Fig. 1 a Location of the study area within states of Penang and Kedah and $\mathbf{b}$ schematic diagram of Riverbank Filtration (RBF) project at Penang and Kedah states

make sure that there were no air bubbles. The bottles were then capped tightly. The samples for the analyses of $\delta^{2} \mathrm{H}$ and $\delta^{18} \mathrm{O}$ underwent treatment in the SerCon Water Equilibration System (WES) before they were analysed using the isotope ratio mass spectrometer (IRMS). Both values of the $\delta^{2} \mathrm{H}$ and $\delta^{18} \mathrm{O}$ were measured in terms of the internal/secondary laboratory standard (MTW). Furthermore, calibration of the values of -45.00 and $-7.23 \%$, respectively, was done 
Table 1 Sampling 24 locations including surface water and groundwater of the study area

\begin{tabular}{|c|c|c|c|c|}
\hline ID & Type & Easting & Northing & Elevation (m) \\
\hline BH1 & GW & $278,462.66$ & $616,401.23$ & 5.76 \\
\hline $\mathrm{BH} 2$ & GW & $278,250.26$ & $616,601.33$ & 4.42 \\
\hline $\mathrm{BH} 3$ & GW & $278,128.43$ & $616,745.43$ & 4.65 \\
\hline $\mathrm{BH} 4$ & GW & $278,054.11$ & $616,761.77$ & 4.39 \\
\hline BH5 & GW & $277,918.56$ & $615,848.71$ & 5.10 \\
\hline BH6 & GW & $277,682.91$ & $615,941.59$ & 5.31 \\
\hline BH7 & GW & $278,753.34$ & $616,117.88$ & 6.01 \\
\hline BH8 & GW & $278,430.51$ & $616,161.46$ & 5.79 \\
\hline BH9 & GW & $278,271.70$ & $616,318.01$ & 5.11 \\
\hline BH10 & GW & $278,142.33$ & $615,783.93$ & 5.30 \\
\hline BH11 & GW & $278,091.15$ & $615,596.62$ & 4.19 \\
\hline BH12 & GW & $277,766.96$ & $615,475.17$ & 5.42 \\
\hline BH13 & GW & $277,568.45$ & $615,738.87$ & 6.01 \\
\hline BH14 & GW & $278,146.80$ & $616,802.80$ & 5.11 \\
\hline BH15 & GW & $278,338.51$ & $616,267.80$ & 5.98 \\
\hline BH16 & GW & $280,190.12$ & $615,475.70$ & 10.55 \\
\hline BH17 & GW & $280,481.16$ & $615,674.14$ & 9.49 \\
\hline BH18 & GW & $281,724.71$ & $615,627.83$ & 12.75 \\
\hline BH19 & GW & $282,535.71$ & $614,540.97$ & 9.39 \\
\hline $\mathrm{BH} 20$ & GW & $284,160.41$ & $616,059.03$ & 16.58 \\
\hline $\mathrm{BH} 21$ & GW & $284,077.06$ & $615,626.44$ & 12.00 \\
\hline $\mathrm{BH} 22$ & GW & $284,916.06$ & $614,320.72$ & 9.85 \\
\hline TW1 & GW & $278,133.80$ & $616,761.64$ & 4.92 \\
\hline TW2 & GW & $278,427.17$ & $616,179.01$ & 5.42 \\
\hline TW3 & GW & $284,943.84$ & $614,169.90$ & 10.97 \\
\hline TW4 & GW & $280,623.43$ & $615,753.44$ & 9.49 \\
\hline Muda River & RW & - & - & - \\
\hline Precipitation & PW & - & - & - \\
\hline
\end{tabular}

with the use of the international standard (VSMOW). For ${ }^{8} \mathrm{O}$ and ${ }^{2} \mathrm{H}$, the expression of their stable isotopic composition is per mil deviation $\left(\delta \%\right.$ ) of the ratio ${ }^{18} \mathrm{O} /{ }^{16} \mathrm{O}$ or ${ }^{2} \mathrm{H} /{ }^{1} \mathrm{H}$ based on the Standard Mean Ocean Water. $\delta^{18} \mathrm{O}$ and $\delta^{2} \mathrm{H}$ had $\pm 0.1 \%$ and $\pm 1.0 \%$ analytical errors, respectively. The samples for the isotope analysis were measured in triplicates for every analytical run so that more conclusive results can be obtained. Equation 1 is used to compute $\delta \%$ :

$\% \circ 0=\left[\frac{R_{\text {sample }}-R_{\text {standard }}}{R_{\text {standard }}}\right] \times 1000$

Generally, the groundwater isotopic composition is managed by meteorological processes and is meant for the $\delta^{2} \mathrm{H}$ and $\delta^{18} \mathrm{O}$ analyses in groundwater system. From the isotope exchange process using the $\delta^{18} \mathrm{O}-\delta^{2} \mathrm{H}$ diagram, the result deviates from the meteoric water line that is found along a line having a lower slope, which is affected by the relative humidity. However, some extreme geological environments

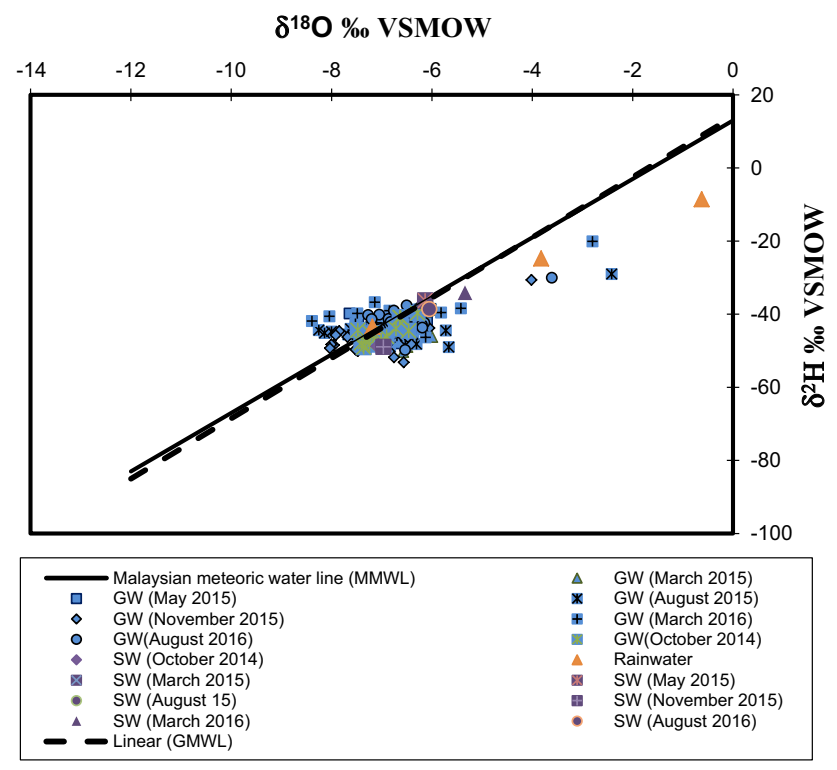

Fig. 2 The isotopic data for precipitation (rainwater), groundwater, and surface water collected during October, November, March, May, August 2014-2016

exist where the meteoric signature of the water can be changed due to the reaction between groundwater and the subsurface gases or the aquifer matrix (Cartwright et al. 2012).

\section{Results and discussion}

Isotope techniques work especially well in identifying the groundwater recharge's source and the interaction that takes place between the groundwater and the surface water. The mechanisms and sources of recharge were identified using the fundamental relationship between $\delta^{2} \mathrm{H}$ and $\delta^{18} \mathrm{O}$. Figure 2 demonstrates the results for all isotope samples found within the study area. The rainfall (RW) composition revealed that the isotopic signature ranged from -43.43 to -8.57 for $\delta^{2} \mathrm{H}$ and from -7.19 to -0.6 for $\delta^{18} \mathrm{O}$. The surface water's (river water) composition also revealed that the range of the isotopic signature was from -48.79 to -34.14 for $\delta^{2} \mathrm{H}$ and -7.06 to -6.05 for $\delta^{18} \mathrm{O}$. Both the groundwater and surface water stable isotope compositions were plotted together along with those for the rainfall that was gathered at the study area (Fig. 2). The Malaysian Meteoric Water Line (MMWL; $\delta^{2} \mathrm{H}=8 \delta^{18} \mathrm{O}$ +13.255; Ayub 2005) and the Global Meteoric Water Line (GMWL; $\delta^{2} \mathrm{H}=8 \delta^{18} \mathrm{O}+10$; Craig 1961) served as reference lines. The plotted points that were nearer or on the MMWL and GMWL lines were likely to undergo direct recharging from local precipitation with minimal evaporation. The overall stable isotopic composition data that

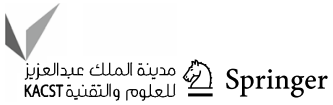


were gathered from river water and groundwater were spread over a range that is relatively small. Groundwater was generally more isotopically ${ }^{18} \mathrm{O}$ enriched. The result revealed that the groundwater samples in the area had isotopic compositions with a narrow range, from -53.18 to -38.79 for $\delta^{2} \mathrm{H}$ and -8.25 to -2.80 for $\delta^{18} \mathrm{O}$. Furthermore, evaporation affected the some of the samples. This narrow isotopic variation indicated that all the groundwater samples came from the same recharge area or the same water regime, mainly from rainfall (non-evaporated and close to the main river (Muda River). This is indicative to the fact that the groundwater is recharged by Muda River in the confined aquifer and that evaporation takes place before the lower aquifer system is recharged.

The $\delta^{2} \mathrm{H}$ and $\delta^{18} \mathrm{O}$ data in rainwater were gathered from the portion of the Muda River Basin that were seen as the representative for the study area and as a provider of isotopic information that was related to the principal recharge source, i.e. precipitation. The isotopic data for groundwater, precipitation (rainwater), and surface water were gathered during October, November, March, May, and August during the years 2014-2016. These data are plotted in Fig. 2 and also presented as part of supplementary Table 1.

Variations in the components' stable isotope composition in a water catchment are due to (a) natural variations in rainfall's isotopic composition, (b) combination with groundwater, and (c) evaporation (Kendall and McDonell 1998; Guglielmi et al. 1998; Hunt et al. 1998; Huddard et al. 1999).
Furthermore, stable isotopes $\delta^{18} \mathrm{O}$ and $\delta^{2} \mathrm{H}$ are important tools that make it possible to trace water movement.

\section{Comparison of $\delta^{18} \mathrm{O}$ and chloride $\left(\mathrm{Cl}^{-}\right)$}

The relationship between $\delta^{18} \mathrm{O}$ and chloride $\left(\mathrm{Cl}^{-}\right)$concentration can also be useful in identifying the groundwater recharge mechanism (Shao 1989; Chen et al. 2006). As demonstrated in Fig. 3, comparing $\delta^{18} \mathrm{O}$ and $\mathrm{Cl}^{-}$data offers more understanding of the scale of the interactions between groundwater and surface water in the Lower Muda River Basin. It is suggested by the chloride $-\delta^{18} \mathrm{O}$ plot (Fig. 3) that there are four types of groundwaters found in the study area: (1) some groundwater that comes from the upstream Lower Muda River Basin and is characterised by relatively ${ }^{18} \mathrm{O}$ enriched and low $\mathrm{Cl}^{-}$, representing areas that are recharged more frequently by high rainfall and less frequently by the river; (2) some groundwater located upstream Lower Muda River Basin and characterised by relatively ${ }^{18} \mathrm{O}$-depleted water and low $\mathrm{Cl}^{-}$; (3) majority of the Lower Muda River Basin's groundwater, characterised by relatively ${ }^{18} \mathrm{O}$-depleted water and by low $\mathrm{Cl}^{-}$, which signifies that it is most often recharged by river water or that the groundwater is recharging the river water; and (4) highly saline groundwater that is found further downstream of Lower Muda River Basin and is characterised by ${ }^{18} \mathrm{O}$-depleted water and very high $\mathrm{Cl}^{-}$, which means that it rarely or never receives any surface water recharge. It has been observed that relatively
Fig. 3 Chloride versus $\delta^{18} \mathrm{O}$ concentration for river water and groundwater in the Lower Muda River Basin

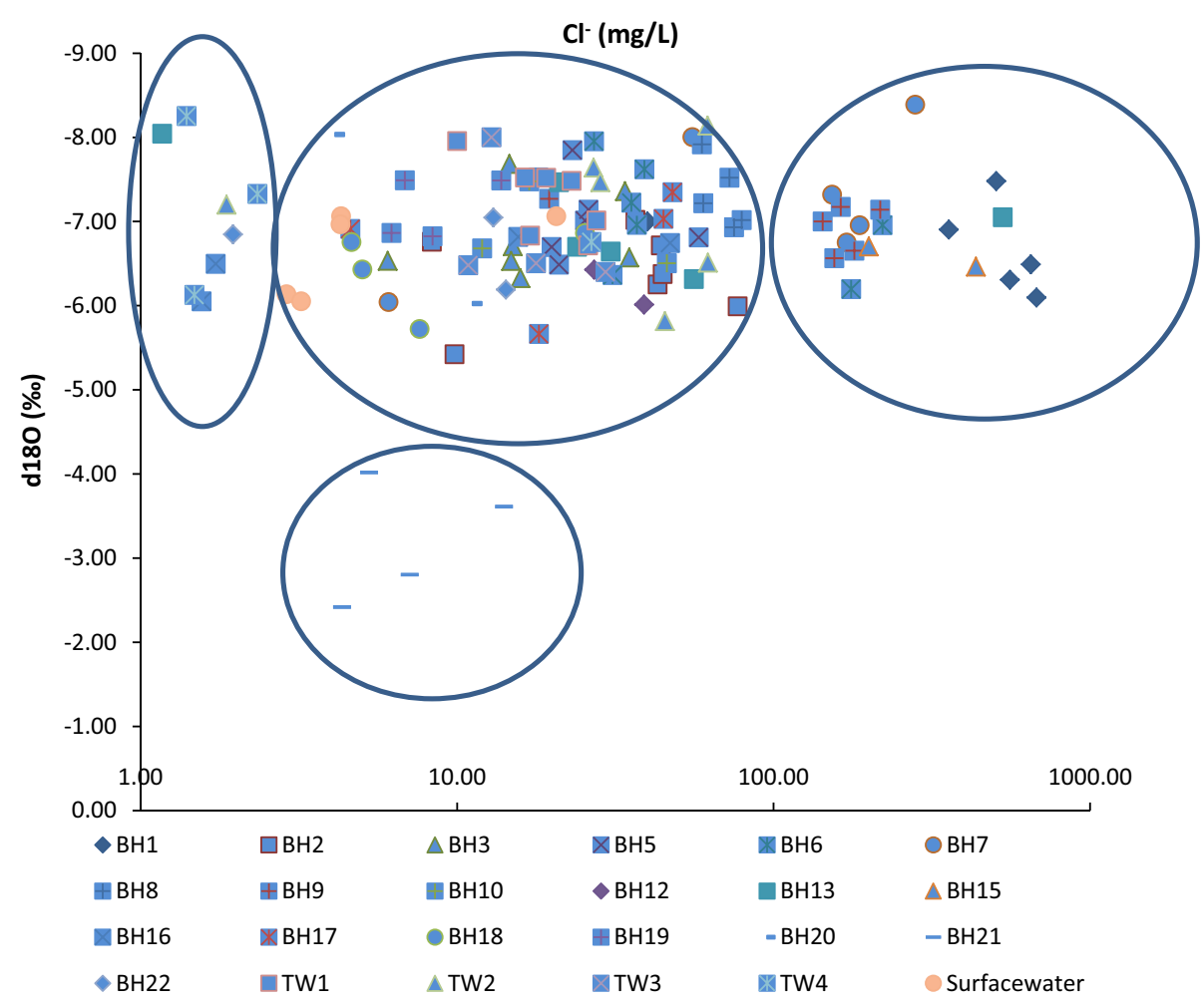


${ }^{18} \mathrm{O}$-depleted water signatures recharging and low $\mathrm{Cl}^{-}$characterise recharging by surface water through bank infiltration, whereas diffuse recharge would have a tendency to be ${ }^{18} \mathrm{O}$ enriched in both $\mathrm{Cl}^{-}$and ${ }^{18} \mathrm{O}$.

\section{Isotopic compositions of precipitation (rainfall)}

For this study, an analysis of a total of five precipitation (rainfall) samples in the Lower Muda River Basin was performed to discuss the rainfall's characteristic isotopic signatures. The precipitation's $\delta^{2} \mathrm{H}$ was between -43.83 and $-8.57 \%$. The range of the $\delta^{18} \mathrm{O}$ was between -7.19 and $-0.62 \%$. This study also examined precipitation's isotopic composition during the dry and wet seasons in Muda River Basin. In wet seasons, the $\delta^{2} \mathrm{H}$ ranged between -24.76 and $-8.57 \%$. On the other hand, the $\delta^{18} \mathrm{O}$ was found to range between -3.82 and $-0.62 \%$. In dry seasons, the $\delta^{2} \mathrm{H}$ ranged between -43.43 and $40.30 \%$. On the other hand, the $\delta^{18} \mathrm{O}$ ranged between -7.19 and $-6.90 \%$ (Fig. 4). Compared to the wet seasons, a more ${ }^{18} \mathrm{O}$ (or D)-depleted water composition and ${ }^{2} \mathrm{H}$ isotopes were observed in the dry seasons. In Malaysia, compared to the northeast monsoon's rainfall in the wet season, the composition of hydrogen isotopes experiences more ${ }^{18} \mathrm{O}$ enriched in the rainfall of the southwest monsoon during dry seasons. Based on the effects of temperature in the atmosphere, the signatures of ${ }^{18} \mathrm{O}$ and ${ }^{2} \mathrm{H}$ isotopes in precipitation may have been enhanced by low temperature. In seasons that experience great rainfall, the isotopes of ${ }^{18} \mathrm{O}$ and ${ }^{2} \mathrm{H}$ in precipitation are significantly lower value in many tropical area due to the rainfall amount effect (Dansgaard 1964), which is brought about by heavy precipitation amounts over a relatively short period of time. Thus, isotopes are also affected by rainfall. The amount of rainfall and temperature has opposite effects on the ${ }^{18} \mathrm{O}$ and ${ }^{2} \mathrm{H}$ isotopes' fractionation. Moreover, the isotopes found in the Muda River Basin experience more ${ }^{18} \mathrm{O}$ enriched during rain seasons than during dry seasons. The ${ }^{18} \mathrm{O}$ and ${ }^{2} \mathrm{H}$ isotopes' signatures can be attributed to the mutual influence that rainfall amount and temperature have, with the effect of the former being stronger than the latter. During seasons of rain in the dry season, there are often heavier and greater amounts of rainfall during a specific period of time, leading to higher precipitation rates despite low temperatures. Consequently, at this time, the ${ }^{2} \mathrm{H}$ and ${ }^{18} \mathrm{O}$ isotopes' composition is depleted in terms of ${ }^{18} \mathrm{O}$ and ${ }^{2} \mathrm{H}$. Yurtesever and Gat (1981) emphasised that generally the effect of temperature is normally more noticeable in high-latitude continental regions, while the effect of amount is more noticeable in tropical regions. It is commonly known that the precipitation's heavy content of ${ }^{2} \mathrm{H}$ and ${ }^{18} \mathrm{O}$ isotopes decreases when the altitude is increased. For this study, the sites of precipitation are found in the basin's lowest area. Thus, in this study, discussing the range of the effect of altitude in the basin is difficult. Precipitation sites may not be an adequate representation of the lower basin's average precipitation. If the effect of altitude is large, groundwater may also derive from the mountainous area's precipitation with ${ }^{18} \mathrm{O}$-depleted water isotopic compositions that is akin to those in streams.

\section{Isotopic compositions of river water}

For the river water in the Muda River Basin, the $\delta^{2} \mathrm{H}$ was between -48.93 and $-34.14 \%$. On the other hand, the range of $\delta^{18} \mathrm{O}$ was from -7.06 to $-5.34 \%$. The comparison of the compositions of $\delta^{2} \mathrm{H}$ and $\delta^{18} \mathrm{O}$ isotopes for the rainwater and river water revealed that the $\delta^{2} \mathrm{H}$ and $\delta^{18} \mathrm{O}$ isotopes from the river water had compositions that matched those from the local meteoric water that are found across the Muda River Basin. This is indicative of the fact that in the river water, rainfall is the primary source. Furthermore, the $\delta^{2} \mathrm{H}$ and $\delta^{18} \mathrm{O}$ isotopes found in the river water had compositions that were more ${ }^{18} \mathrm{O}$-depleted water compared to the precipitation that was observed in the valley, which that the river water is made up of rainfall in the upstream catchment. Thus, the precipitation in the valley had more minimal influence on the river water. During wet seasons, the isotopes of $\delta^{2} \mathrm{H}$ and $\delta^{18} \mathrm{O}$ possessed a more ${ }^{18} \mathrm{O}$-enriched composition in comparison with dry seasons, a phenomenon that is similar to the rainwater. Thus, the seasons influence the composition of the rainwater. In short, one can conclude that seasonal rainfall significantly affects the Muda River Basin's water recharge. Furthermore, as previously mentioned, the compositions of the $\delta^{2} \mathrm{H}$ and $\delta^{18} \mathrm{O}$ isotopes of the rainfall that is brought about by the southwest monsoon during the dry season experience more depletion compared to the northeast monsoon during the wet season.

This study also compared the signatures of the $\delta^{2} \mathrm{H}$ and $\delta^{18} \mathrm{O}$ isotopes for the river water in the Muda River main stream during dry and rainy seasons. Figure 5 illustrates

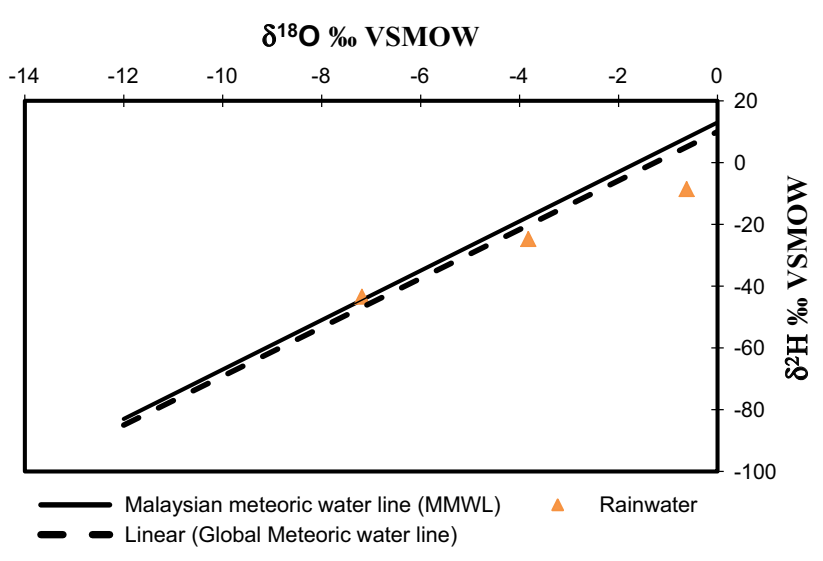

Fig. 4 Plot of $\delta^{2} \mathrm{H}$ versus $\delta^{18} \mathrm{O}$ for precipitation samples for wet and dry seasons. LMWL represents the local meteoric water line

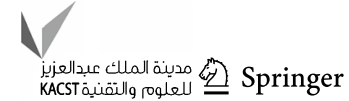



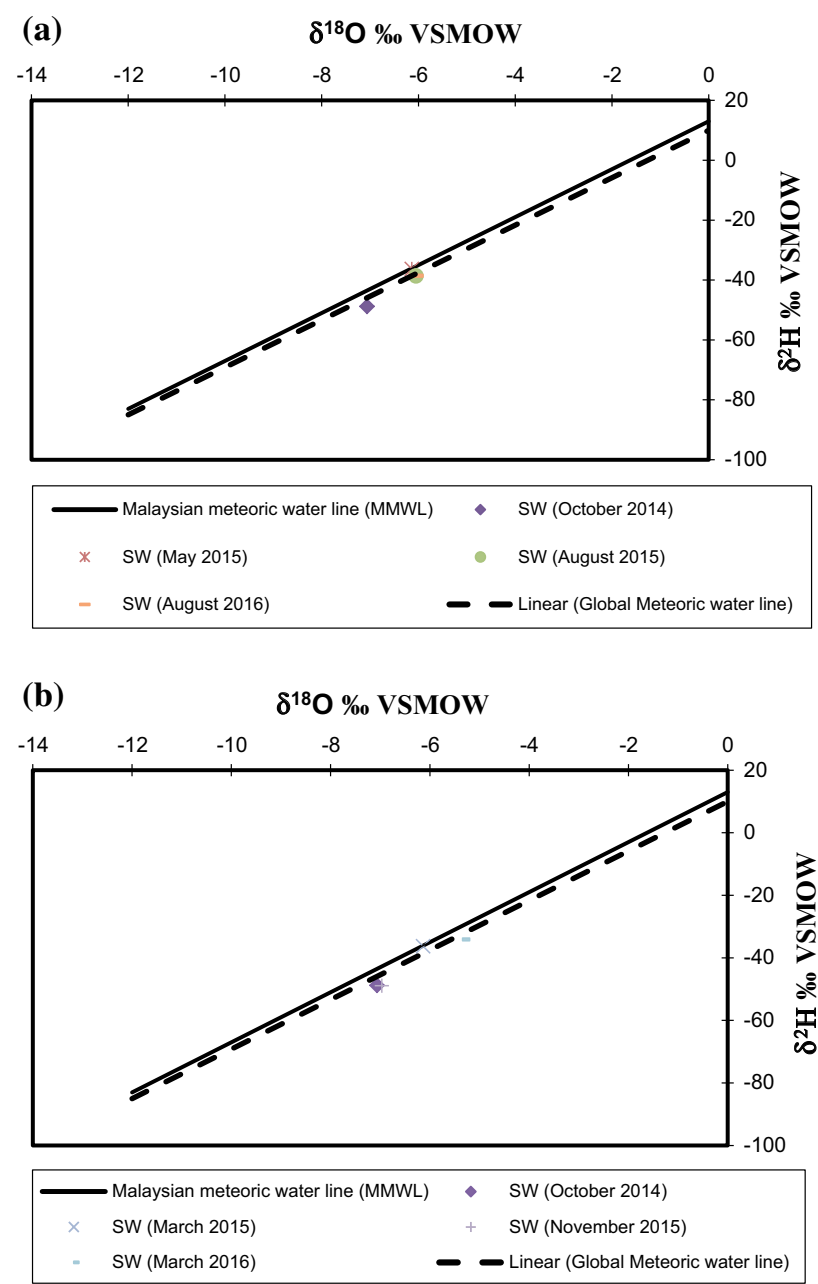

Fig. 5 Plot of $\delta^{2} \mathrm{H}$ versus $\delta^{18} \mathrm{O}$ for river water samples during a dry season and $\mathbf{b}$ wet seasons

that there are significant differences in the signatures of the $\delta^{2} \mathrm{H}$ and $\delta^{18} \mathrm{O}$ isotopes in the mainstream of the Muda River. The river leaks water into the groundwater system during rainy seasons. Alternatively, in dry seasons, water may be discharged from the groundwater to surface waters. Thus, the compositions of the groundwater were similar to the compositions of the river water, which is an indication that in this area, the source of the groundwater may be linked to the rivers water. During both dry and rainy seasons, the river of the Muda River had isotope signatures having more depleted interflow. Interflow refers to the water's lateral movement in the vadose zone that first enters a river or returns to the surface before becoming groundwater. The interflow mixes with groundwater before joining the Muda River. Consequently, those two had significantly different compositions. Verification of these results may need to be performed by gathering related data.
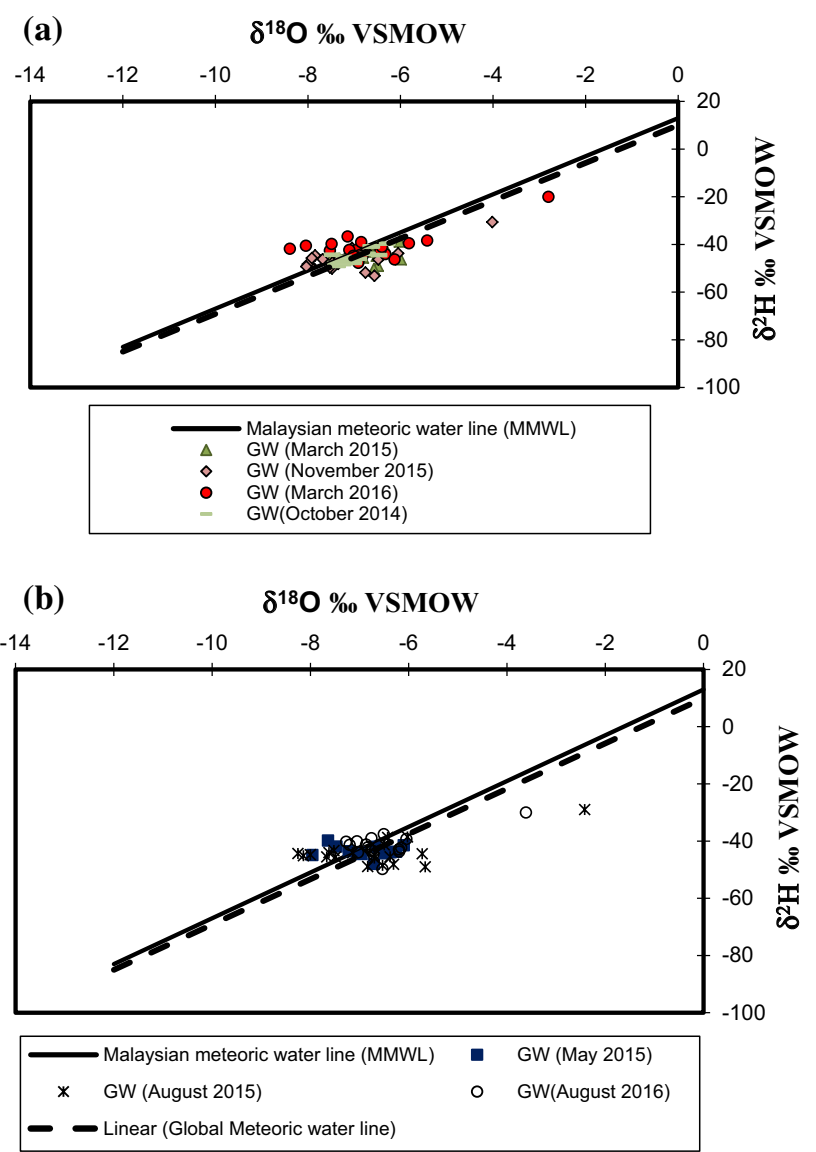

Fig. 6 Relationship between $\delta^{2} \mathrm{H}$ and $\delta^{18} \mathrm{O}$ for groundwater during a wet seasons and $\mathbf{b}$ dry season

\section{Isotopic compositions of groundwater}

This research involved groundwater analysis in the Muda River Basin. Figure 6 illustrates the compositions of $\delta^{2} \mathrm{H}$ and $\delta^{18} \mathrm{O}$ isotopes in the groundwater samples that were gathered from the monitoring wells situated along the Lower Muda River Basin. In the Muda River Basin, the $\delta^{2} \mathrm{H}$ of the groundwater was between -53.18 and $-20.10 \%$, having a mean of $-36.5 \%$ o. The range of $\delta^{18} \mathrm{O}$ was from -8.25 to $-2.80 \%$, having a mean of $-5.52 \%$. The river water isotopic composition is managed by the mixing rates for the three main components: interflow, surface run-off, and groundwater (base flow). The rainfall and river water has recharged the basin groundwater. For this study, the compositions of groundwater are similar to those of the river water, which is an indication that in this area, the source of groundwater may be linked to the river water (interaction). Instead of a simple rainfall recharge, the primary groundwater source could be river water. Furthermore, the isotopes of hydrogen and oxygen in the groundwater that is close to the Muda River exhibited a slight deviation from the isotopes of $\delta^{2} \mathrm{H}$ and $\delta^{18} \mathrm{O}$ of the local meteoric water line found in 
the Lower Muda River. Thus, the groundwater could be a combination of river water and rainwater, which could be the reason why the river water recharge had a greater effect compared to the rainfall infiltration. For the wells, the $\delta^{18} \mathrm{O}$ and $\delta^{2} \mathrm{H}$ isotopic concentration ranged from -8.39 to -2.42 and had a mean of -6.78 and -53.18 to -20.10 along with a mean of -43.61 , respectively. Based on the plot (Fig. 6), it is observable that the sampled monitoring found along the meteoric water lines (MMWL and GMWL) offers evidence of a meteoric origin and the isotopic enhancement through evaporation in the unsaturated zone or on the surface prior to recharge. It is also suggested by the plot (Fig. 6) that direct infiltration of rainwater is likely recharging the groundwater. The monitoring wells' plot also seemed to be grouped within a narrow range, which indicates a mixed system that is well balanced and has a relatively constant isotopic composition.

\section{Deuterium excess factor}

The value of deuterium excess (d-excess) can be computed using the equation that Dansgaard (1964) formulated as: $d=\delta^{2} \mathrm{H}-8 \delta^{18} \mathrm{O}$. The value of the d-excess can be more than $10 \%$, and it can also range around $9.823 \%$ in Muda River. Figure 7 demonstrates the relationship between the 180 and the d-excess for the study area. The range of the value of the d-excess is situated between 25.25 and $-9.67 \%$ o. This broad range in the observed d-excess values is a reflection of the interaction of recent recharge waters, which were ${ }^{18} \mathrm{O}$ enriched in $\delta^{18} \mathrm{O}$ values that were taken from rainfall that had low mineralisation, and also for those ${ }^{18} \mathrm{O}$-depleted water in $\delta^{18} \mathrm{O}$ values (Maduabuchi et al. 2006; Hoefs 2009;
Wassenaar et al. 2011). Based on the findings of Samir (2011), the low values for the d-excess $(\leq 6 \%$ o) that were observed in the study area's waters were the indications that there was a significant rainwater evaporation, which meant that the residual groundwater was left behind and that they had lower 'd-excess' values. The d-excess value that is $>10 \%$ is an indication that the source of the recharge is from mixed continental and oceanic vapour (Samir 2011). The d-excess constituent that Dansgaard (1964) defined makes it possible to relate any water sample's isotopic composition to the meteoric water line. Thus, the distribution of values possesses a meteorological significance (Onugba et al. 1990). Generally, the d-excess values exhibit a deviation from $10 \%$ (Fig. 7). The high values of d-excess are indicative of a evaporative flux from continental waters. It is also considered as a main contributor to the air mass' total moisture balance (Onugba et al. 1990). In this instance, high values of d-excess $(>10 \%$ ) are the indication that the evaporative flux from west Malaysia has more significant contributions to the precipitation that is responsible for recharging the groundwater.

\section{Conclusion}

The study has evaluated the isotope hydrology of rivers, rainfall, and groundwater within the Lower River Muda Basin. Gaining a comprehension of the sources of recharge, their mechanisms, and their changes are vital in managing groundwater resources to sustainably satisfy current and future requirements in the Lower Muda River Basin.
Fig. 7 Relationship between $\delta^{18} \mathrm{O}(\% 0)$ and d-excess for Lower Muda River Basin aquifer

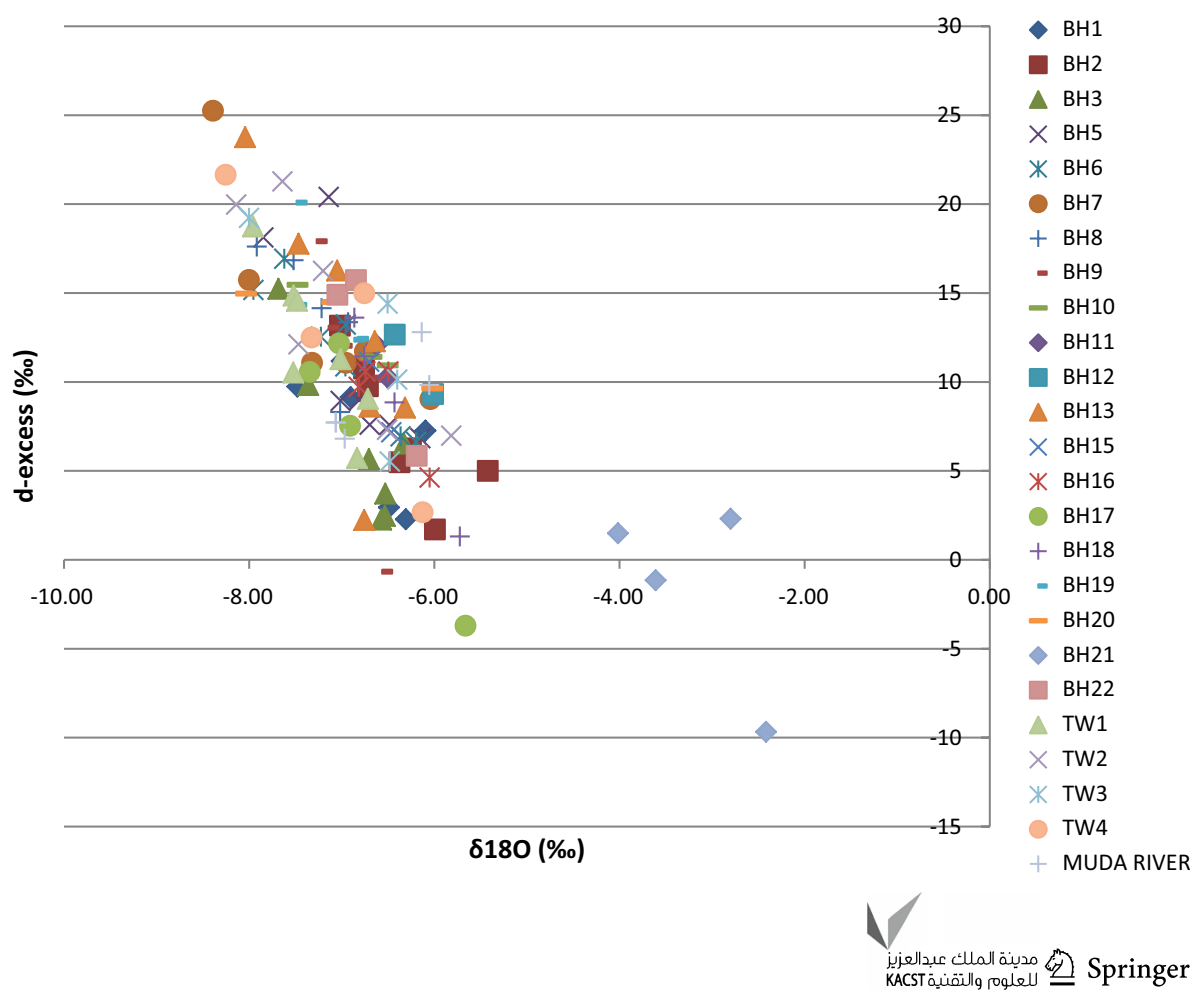


In terms of the characteristics of $\mathrm{Cl}^{-}$concentrations and $\delta^{2} \mathrm{H}$ and $\delta^{18} \mathrm{O}$ compositions, the recharge sources were successfully determined. The composition of the stable isotopes $\delta^{2} \mathrm{H}$ and $\delta^{18} \mathrm{O}$ was also successfully determined in the studied waters (river, rainfall, and groundwater). Comparisons between the isotopes of $\delta^{2} \mathrm{H}$ and $\delta^{18} \mathrm{O}$ in precipitation revealed that variations in the rainfall amount were resulted the enrichment of $\delta^{2} \mathrm{H}$ and $\delta^{18} \mathrm{O}$ isotopes for precipitation in wet seasons compared to precipitation in dry seasons. Compared to precipitation, river water had more ${ }^{18} \mathrm{O}$-depleted water isotopes of $\delta^{2} \mathrm{H}$ and $\delta^{18} \mathrm{O}$, which signified that the river water was mostly sourced from the upstream catchment. Based on the river, rainfall, and groundwater samples gathered, one can conclude that in the hydrology system groundwater and surface water interact between each other and river water recharges discharge to groundwater depending on rainy and dry season.

The results from the environmental isotope and hydrochemical sampling from the Lower Muda River area are the indications that the perennial river as well as the shallow alluvial aquifer that is near the river in the Lower Muda River Basin area has a relationship that can be called hydraulic interaction. In the Lower Muda River Basin during wet season, the river is mainly losing and recharging the shallow aquifer. With the use of data for the environmental isotope, the alluvial aquifer's recharge by surface water takes place via riverbank filtration and diffuses recharge during events of high rainfall. Although data from the hydrochemical $\left(\mathrm{Cl}^{-}\right)$ and environmental isotope indicate a relationship between the river and shallow groundwater, one needs more timeseries data so that the seasonal change to connectivity can be defined. This is the useful information in gaining a better understanding of the hydrogeological processes taking place at the river aquifer interface and how they are connected to the biogeochemical processes and the policies for water allocation.

Acknowledgements The present study was funded as part of the Ministry of Natural Resources and Environment (NRE) to this study under National Water Resources Council (P23101110117300). Many colleagues have contributed to this study. We would like to thank the staffs of the National Hydraulic Research Institute of Malaysia (NAHRIM), for their technical assistance and analysing the samples.

Open Access This article is distributed under the terms of the Creative Commons Attribution 4.0 International License (http://creativeco mmons.org/licenses/by/4.0/), which permits unrestricted use, distribution, and reproduction in any medium, provided you give appropriate credit to the original author(s) and the source, provide a link to the Creative Commons license, and indicate if changes were made.

\section{References}

Ayub MS (2005) Malaysian meteoric water line: an input to isotopes hydrological studies. TAG Brown Bag Seminar no. 1, Malaysia Institute for Nuclear Technology Research (MINT), Selangor, Malaysia

Bhattacharya SK, Gupta SK, Krishnamurthy RV (1985) Oxygen and hydrogen isotope ratios in groundwaters and rivers from India. Proc Indian Acad Sci (Earth Planet Sci) 94:283-295

Blasch KW, Bryson JR (2007) Distinguishing sources of ground water recharge by using $\delta^{2} \mathrm{H}$ and $\delta^{18} \mathrm{O}$. Ground Water 45:294308. https://doi.org/10.1111/j.1745-6584.2006.00289.x

Bosch JHA (1986) Young Quaternary sediments in the coastal plain of Southern Perak, Peninsular Malaysia. Geology Survey Malaysia Quaternary Geology Report. 1186, 83 pp

Brunner N, Starkl M, Sakthivel P, Elango L, Amirthalingam S, Pratap CE, Thirunavukkarasu M, Parimalarenganayaki S (2014) Policy preferences about managed aquifer recharge for securing sustainable water supply to Chennai City, India. Water 6(12):3739-3757. https://doi.org/10.3390/w6123739

Cartwright I, Weaver TR, Cendón DI, Fifield LK, Tweed SO, Petrides B, Swane I (2012) Constraining groundwater flow, residence times, inter-aquifer mixing, and aquifer properties using environmental isotopes in the southeast Murray Basin, Australia. Appl Geochem 27(9):1698-1709. https://doi.org/10.1016/j. apgeochem.2012.02.006

Chapman TG, Malone RW (2002) Comparison of models for estimation of groundwater recharge, using data from a deep weighing lysimeter. Math Comput Simul 59(1):3-17. https://doi. org/10.1016/S0378-4754(01)00389-5

Chen ZY, Wan L, Nie ZL, Shen JM, Chen JS (2006) Identification of groundwater recharge in the Heihe Basin using environmental isotopes. Hydrogeol Eng Geol 33(6):9-14

Clark ID, Fritz P (1997) Environmental isotopes in hydrogeology. CRC Press, Boca Raton

Coplen TB, Herczeg AH, Barnes C (2000) Isotope engineeringusing stable isotopes of the water molecule to solve practical problems. In: Environmental tracers in sub surface hydrology. Springer US, Berlin, pp 79-110

Courtier DB (1974) Geology and mineral resources of the neighbourhood of Kulim, Kedah. Geological Survey of Malaysia Map Bulletin 3, $50 \mathrm{pp}$

Craig H (1961) Isotopic variations in meteoric waters. Science 133(3465): 1702-1703

Custodio E (2002) Aquifer overexploitation: what does it mean? Hydrogeol J 10(2):254-277. https://doi.org/10.1007/s1004 0-002-0188-6

Dalin C, Wada Y, Kastner T, Puma MJ (2017) Groundwater depletion embedded in international food trade. Nature 543(7647):700

Dansgaard W (1964) Stable isotopes in precipitation. Tellus 16(4):436468. https://doi.org/10.3402/tellusa.v16i4.8993

Grindley J (1969) The calculation of evaporation and soil moisture deficit over specified catchment area, Hydrological Memorandum 28. Meteorological Office, Bracknell

Guglielmi Y, Mudry J, Blavoux B (1998) Estimation of the water balance of alluvial aquifers in region of high isotopic contrast: an example from southeastern France. J. Hydrol. 210:106-115. https ://doi.org/10.1016/S0022-1694(98)00178-4

Hoefs J (2009) Stable isotope geochemistry, 6th edn. Springer, Berlin, Heidelberg, pp 36-87

Hough MN, Jones RJA (1998) The United Kingdom Meteorological Office rainfall and evaporation calculation system: MORECS version 2.0-an overview. Hydrol Earth Syst Sci 1:227-239

Huddard PA, Longstaffe FJ, Crowe AS (1999) $\delta D$ and $\delta^{18} O$ evidence for inputs to groundwater at a wetland coastal boundary in the 
southern Great Lakes region of Canada. J. Hydrol. 214:18-31. https://doi.org/10.1016/S0022-1694(98)00226-1

Hunt R, Bullen TD, Krabbenhoft DP, Kendall C (1998) Using stable isotopes of water and strontium to investigate the hydrology of a natural and a constructed wetland. Groundwater 36:434-443. https ://doi.org/10.1111/j.1745-6584.1998.tb02814.x

IAEA (International Atomic Energy Agency) (2011) Using isotopes effectively to support comprehensive groundwater management-NTR 2011 Supplement. 55th IAEA General Conference Documents

Jasechko S, Kirchner JW, Welker JM, McDonnell JJ (2016) Substantial proportion of global streamflow less than three months old. Nat Geosci 9(2):126-129

Kamaludin BH (1989) Palynology of the lowland Seberang Prai and Kuala Kurau Areas north-west Peninsular Malaysia. Geol Soc M'sia Bull 23:199-215

Kamaludin BH (1990) A summary of the Quaternary geology investigations in Seberang Prai, Pulau Pinang and Kuala Kurau. Geol Soc Malays Bull 26:47-53

Kendall C, McDonnell JJ (1998) Isotope tracers in catchment hydrology. United States, Elsevier, New York, p 839

Krishnamurthy RV, Bhattacharya SK (1991) Stable oxygen and hydrogen isotope ratios in shallow groundwater from India and a study of the role of evapotranspiration in the Indian monsoon. In: Kumar D (ed) Groundwater management in India: physical, institutional and policy alternatives. Sage Publications, New Delhi

Kumar D (2007) Groundwater management in India: physical, institutional and policy alternatives. Sage Publications, New Delhi

Kyle WB, Jeannie RB (2007) Distinguishing sources of groundwater recharge by using $\delta 2 \mathrm{H}$ and $\delta^{18} \mathrm{O}$. Ground Water 45(3):294-308. https://doi.org/10.1111/j.1745-6584.2006.00289.x

Lee KS, Lee CB (1999) Oxygen and hydrogen isotopic composition of precipitation and river waters in South Korea. J Geol Soc Korea 35:73-84

Li F, Pan G, Tang C, Zhang Q, Yu J (2008) Recharge source and hydrogeochemical evolution of shallow groundwater in a complex alluvial fan system, southwest of North China Plain. Environ Geol 55:1109-1122. https://doi.org/10.1007/s00254-007-1059-1

Ma J, Huang T, Ding Z, Edmunds WM (2007) Environmental isotopes as the indicators of the groundwater recharge in the South Badain Jaran Desert. Adv Earth Sci 22(9):922-930

Maduabuchi C, Faye S, Maloszewski P (2006) Isotope evidence of paleorecharge and paleoclimate in the deep confined aquifers of the Chad Basin. NE Nigeria. Sci. Total Environ. 370:467-479. https://doi.org/10.1016/j.scitotenv.2006.08.015

Mandal AK, Zhang J, Asai K (2011) Stable isotopic and geochemical data for inferring sources of recharge and groundwater flow on the volcanic island of Rishiri, Japan. Appl Geochem 26:1741-1751. https://doi.org/10.1016/j.apgeochem.2011.05.001

Mukherjee A, Fryar AE, Rowe HD (2007) Regional-scale stable isotopic signatures of recharge and deep groundwater in the arsenic affected areas of West Bengal, India. J Hydrol 334:151-161. https ://doi.org/10.1016/j.jhydrol.2006.10.004

Onodera S, Kitaoka K, Hayashi M, Shindo S, Kusakabe M (1995) Evaluation of the groundwater recharge process in a semiarid region of Tanzania, using $\delta^{2} \mathrm{H}$ and $\delta^{18} \mathrm{O}$ Application of Tracers in Arid Zone Hydrology. In: Proceedings of the Vienna Symposium August 1994, vol 232. The International Association of Hydrological Sciences (IAHS) Publications, pp 383-391

Onugba A, Blavoux B, Dray M (1990) The environmental isotopes in monthly precipitation at Kano (Nigeria) from 1961-1973. In: Proceedings of the 1st biennial national hydrology symposium, Maiduguri, UNESCO, pp 67-88

Palmer PC, Gannett MW, Hinkle SR (2007) Isotopic characterization of three groundwater recharge sources and inferences for selected aquifers in the upper Klamath Basin of Oregon and
California, USA. J Hydrol 336:17-29. https://doi.org/10.1016/j. jhydrol.2006.12.008

Samir AG (2011) An assessment of recharge possibility to NorthWestern Sahara Aquifer System (NWSAS) using environmental isotopes. J. Hydrol. 398:184-190. https://doi.org/10.1016/j.jhydr ol.2010.12.004

Scanlon BR, Keese KE, Flint AL, Flint LE, Gaye CB, Edmunds WM, Simmers I (2006) Global synthesis of groundwater recharge in semiarid and arid regions. Hydrol Process 20(15):3335-3370. https://doi.org/10.1002/hyp.6335

Sear DA, Armitage PD, Dawson FH (1999) Groundwater dominated rivers. Hydrol Process 13(3):255-276

Shamsuddin MKN, Sulaiman WNA, Suratman S, Zakaria MP, Kamarudin S (2014) Groundwater and surface-water utilisation using a bank infiltration technique in Malaysia. Hydrogeol $\mathrm{J}$ 22(3):543-564. https://doi.org/10.1007/s10040-014-1122-4

Shao YS (1989) Environmental isotope geochemistry of groundwater in Hohhot Basin, inner Mongolia. Geotech Invest Surv 4:41-43 (in Chinese)

Shao JL, Xu YX, Cui YL, Yuan CM, Wang LH (2006) Study on groundwater change on the Aberrance condition in Hubao Plain, Inner Mongolia. China. Geoscience 20(3):480-485

Suntharalingam T, Teoh LH (1985) Quaternary geology of the coastal plain of Taiping, Perak. Geol Surv Malays Quat Geol Bull 1:64

Tamez-Meléndez C, Hernández-Antonio A, Gaona-Zanella PC, Ornelas-Soto N, Mahlknecht J (2016) Isotope signatures and hydrochemistry as tools in assessing groundwater occurrence and dynamics in a coastal arid aquifer. Environ Earth Sci 75(9):830. https://doi.org/10.1007/s12665-016-5617-2

Taylor RG, Scanlon B, Döll P, Rodell M, Van Beek R, Wada Y, Longuevergne L, Leblanc M, Famiglietti JS, Edmunds M, Konikow L (2013) Ground water and climate change. Nat Clim Change 3(4):322

Unsal B, Yagbasan O, Yazicigil H (2014) Assessing the impacts of climate change on sustainable management of coastal aquifers. Environ Earth Sci 72:2183-2193. https://doi.org/10.1007/s1266 5-014-3130-z

Vandenschrick G, Wesemael BV, Frot E, Pulido A, Molina L, Stievenard $\mathrm{M}(2002)$ Using stable isotope analysis $\delta \mathrm{D}-\delta^{18} \mathrm{O}$ ) to characterize the regional hydrology of the Sierra de Gador, south east Spain. J Hydrol 265:43-55. https://doi.org/10.1016/S0022 $-1694(02) 00097-5$

Wassenaar LI, Athanasopoulos P, Hendry MJ (2011) Isotope hydology of precipitation, surface and groundwaters in the Okanagan valley, Britian Columbia. Canada. J. Hydrol. 411:37-48. https://doi. org/10.1016/j.jhydrol.2011.09.032

Yang LP, Jiang ZJ, Zhao YT, Zha ES (2009) Recharge on changes and prediction of trend of the groundwater regime in Hohhot. Hydrogeol Eng Geol 4:46-49 (in Chinese)

Yeh HF, Chen JF, Lee CH (2004) Application of a water budget to evaluate rainfall recharge and slope stability. J Chin Inst Environ Eng 14:1-10

Yeh HF, Lee CH, Hsu KC, Chang PH, Wang CH (2009) Using stable isotopes for assessing the hydrologic characteristics and sources of groundwater recharge. J Environ Eng Manag 19(4):185-191

Yuan RQ, Song XF, Zhang YH, Han DM, Wang SQ, Tang CY (2011) Using major ions and stable isotopes to characterize recharge regime of a fault-influenced aquifer in Beiyishui River Watershed, North China Plain. J Hydrol 405:512-521. https://doi. org/10.1016/j.jhydrol.2011.05.048

Yurtesever Y, Gat JR (1981) Atmospheric waters. In: Gat JR, Gonfiantini R (eds) Stable isotope hydrology: deuterium and oxygen-18 in the water cycle; IAEA Technical Report Series No. 210; International Atomic Energy Agency, Vienna, pp 103-142

Zhang GH, Nie ZL, Xie RB, Chen ZY, Cheng XX, Shen JM, Wang JZ (2005) Isotopic characteristics of groundwater and its renewal in

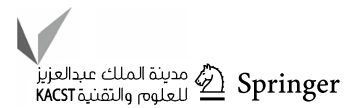


the plain area of western Gansu. Geol Bull China 24(2):149-155

(in Chinese)

Publisher's Note Springer Nature remains neutral with regard to jurisdictional claims in published maps and institutional affiliations. 